\title{
Archaeological Testing of Sites 41TG114, 41TG115, and 41TG116 Tom Green, Texas
}

Wayne C. Young

Follow this and additional works at: https://scholarworks.sfasu.edu/ita

Part of the American Material Culture Commons, Archaeological Anthropology Commons, Environmental Studies Commons, Other American Studies Commons, Other Arts and Humanities Commons, Other History of Art, Architecture, and Archaeology Commons, and the United States History Commons

Tell us how this article helped you.

This Article is brought to you for free and open access by the Center for Regional Heritage Research at SFA ScholarWorks. It has been accepted for inclusion in Index of Texas Archaeology: Open Access Gray Literature from the Lone Star State by an authorized editor of SFA ScholarWorks. For more information, please contact cdsscholarworks@sfasu.edu. 


\section{Archaeological Testing of Sites 41TG114, 41TG115, and 41TG116 Tom Green, Texas}

\section{Licensing Statement}

This is a work produced for the Texas Department of Transportation (TxDOT) by the report producer. TxDOT and the report producer jointly own all rights, title, and interest in and to all intellectual property developed under TXDOT's contract with the report producer. The report may be cited and brief passages from this publication may be reproduced without permission provided that credit is given to both TXDOT and the report producer. Permission to reprint an entire chapter, section, figures or tables must be obtained in advance from either the Supervisor of the Archeological Studies Branch, Environmental Affairs Division, Texas Department of Transportation, 125 East 11th Street, Austin, Texas, 78701 or from the report producer. 
Archaeological Testing of Sites 41 TG 114, 41 TG 115, and 41 TG 116

Tom Green County, Texas

Wayne C. Young

Texas

State Department of Highways and Public Transportation

Highway Design Division

October 1980 


\begin{abstract}
During September 1980, archaeological sites 41 TG 114, 41 TG 115, and $41 \mathrm{TG} 116$ were tested for prehistoric cultural debris to determine their size, depth, cultural affiliations, and archaeological significance.

Testing was conducted by the Archaeology Section of the State Department of Highways and Public Transportation under the Procedures for the Protection of Cultural and Historic Properties (36 C.F.R., Part 800).

Testing results indicate that these sites contain very little cultural debris or intact stratigraphic deposits. Sites 41 TG 114 and 41 TG 116 appear to represent very minor surface campsites. Site 41 TG 115 appears to represent a deflated site with materials mixed on the present ground surface. No further testing is recommended due to the very low densities of cultural materials and the lack of a valid archaeological context at any of the sites. These sites do not meet the qualifications for inclusion in the National Register of Historic Places.
\end{abstract}




\section{INTRODUCTION}

The following report deals with the testing results of three archaeological sites located in southern Tom Green County about 0.1 mile west of Christoval, Texas (Fig. 1). The sites, 41 TG 114, 41 TG 115, and 41 TG 116, are located along the proposed new alignment of U.S. 277 near its intersection with the South Concho River. Testing of the sites was performed by the Archaeology Section of the State Department of Highways and Public Transportation in accordance with the Procedures for the Protection of Cultural and Historic Properties (36 C.F.R., Part 800) during September of 1980.

The proposed right-of-way through the site areas follows an abandoned Atchinson, Topeka, and Santa Fe railroad bed. The railroad bed and adjacent borrow pits largely fill the proposed right-of-way, with as much as $90 \%$ of the proposed alignment showing signs of disturbance of the natural soil zones.

Testing procedures involved the excavation by hand of 1 -meter and 2-meter squares in arbitrary $10 \mathrm{~cm}$ levels through the suspected cultural deposits. Heavy power equipment was not employed in the testing program since natural profiles along the borrow pit walls were available for viewing the stratigraphy. Test units were located in undisturbed portions of the right-of-way as near as possible, both horizontally and vertically, to concentrations of prehistoric cultural debris.

The following sections describe each site individually, the testing procedures, and the results of the testing. All three sites were found to be lacking in depth and appear to represent either surface or deflated sites. All also contain very low densities of prehistoric occupational debris and appear to be of little value in the understanding of the prehistory of west Central Texas.

SITE 41 TG 114

Archaeological Site 41 TG 114 is a small burned rock scatter located about 300 meters north of the present course of the South Concho River. The site is situated in a floodplain area with dense galleria vegetation typical of floodplains in the area. Periodic inundation appears to be a fairly common occurrence; consequently, the railroad bed had been built up 16 feet on the site in an effort to keep the tracks above flood level. 
This Page Redacted Per THC Policy 
The site is indicated by a badly disturbed burned rock scatter lying in a disturbed area east of the road bed on what is now a small knoll. The configuration of the original land surface in the area is difficult to determine due to the railroad construction and subsequent use of heavy equipment to clear the land.

Surface indications of prehistoric occupations at Site 41 TG 114 suggest a probable occupation area approaching 10 meters in diameter. The only visible debris consists of the burned limestone fragments at the assumed original ground level. Flint flakes were extremely rare.

Four test units were excavated at and near the site to determine the depth and density of the occupation. Test Pit 1 was located 15 meters east of the site margins, Test Pit 2 was located at the eastern margins of the site, and Test Pits 3 and 4 were dug where the burned rocks were visible in the cut made by past railroad construction,

Test Pit 1 Was a 1 -meter square excavated in 8 arbitrary $10-\mathrm{cm} 1 \mathrm{eve} 1 \mathrm{~s}$. One flake was found in Level 6, with the remaining 7 levels being sterile. This test pit was taken down into hard basal clays.

Test Pit 2 was a 2 -meter square for the upper 4 levels and then was reduced to a $1-$ meter square for 4 levels due to the complete lack of cultural debris in the upper $40 \mathrm{~cm}$. One flake was found in Level 5.

Test Pits 3 and 4 were both 2 -meter squares which were placed contiguously to expose the burned rocks showing in the railroad construction cut. The burned rocks and what is thought to have been the original ground surface were reached in Level 3. A total of 4 flakes was found from both units along with 8 pieces of charcoal. A burned rock scatter was found in Level 3 , and most of this feature appears to have been destroyed by railroad construction. No materials were found beneath this feature.

Site 41 TG 114 produced the only feature found at the three sites and is interpreted as representing a minor surface occupation. Indication of subsurface occupation was limited to 2 flakes from different levels of different test units.

This site does not appear to warrant further research for several reasons. The site is limited to the pre-construction ground surface, and virtually a 11 of this surface has been removed or has been badly disturbed. Densities of cultural debris are so low as to be virtually nonexistent. This lack of materials and lack of context leaves little that the site can contribute to the prehistory of west Central Texas. 
SITE TG 115

Archaeological Site 41 TG 115 is located about 50 meters inland from the north bank of the South Concho River in a flood-prone environment. The north bank is about 5 meters lower than the south bank of the river and appears to frequently flood whenever a heavy cloudburst occurs upstream from the sites. Flood debris covered portions of this site during our testing program.

The site is indicated by a number of flint flakes and mussel shell fragments lying on a deflated portion of the railroad bed. No diagnostic artifacts were found, although 75 to 80 flakes were visible. It was impossible for our crew to determine the horizontal extent of the site due to the extreme disturbed nature of the area and also to the fact that the site appears to extend outside the right-of-way and it was impossible to gain access to these lands.

Testing was performed by excavating a 1-meter square, $80 \mathrm{~cm}$ deep, into the edge of a railroad construction cut 10 meters east of the flake concentration. This test produced a flake from Level 1 and a flake from Level 3, with the other levels being culturally sterile. This excavation continued to a depth lower than the surface accumulation of flakes and suggests that the site is largely deflated and that the remaining portion in the construction cut wall represents a very low density occupation which will provide little or no additional data on the prehistory of the area. Additional research is not warranted at Site 41 TG 115.

SITE 41 TG 116

Archaeological Site 41 TG 116 is located along the south bank of the South Concho River. This site is located on the higher river bank and is approximately 6 meters above the present river level. This site would not be expected to flood as frequently as Sites 41TG 114 and 41 TG 115.

The dominant flora is mesquite and prickly pear. The mesquite tress on the site are much smaller than those immediately across the property line, probably indicating that the site has been root plowed in recent years in an effort to eliminate the mesquites from the pasture.

The site is indicated by a burned rock scatter extending 50 meters along the river and about 200 meters away from the river. Virtually all of the site is outside the proposed right-of-way with only a small area adjacent to the river available for testing in undisturbed contexts. 
One test pit, a 2-meter square, was excavated to a depth of $50 \mathrm{~cm}$, with no cultural materials recovered beneath Level 1. Thirteen flint flakes were recovered from the first level.

A natural profile on the river bank was also cleaned and examined for cultural materials and buried soil zones. Gravels began to appear at $50 \mathrm{~cm}$ and continued downward to the present water table. No occupational zones were visible.

Site 41 TG 116 appears to represent a low density surface site. The lack of prehistoric cultural materials in stratigraphic association negates the value of the site for additional research.

\section{CONCLUSIONS}

Testing of archaeological Sites 41 TG 114, 41 TG 115, and 41 TG 116 indicates that the sites were either surface or deflated sites with almost no cultural debris in stratigraphic associations. The lack of context and the low density of materials place severe limits on the significance of the sites. None meet the criteria for inclusion in the National Register of Historic Places. Additional research on these sites does not appear warranted. 